\title{
article
}

\section{New urban activisms in Spain: reclaiming public space in the face of crises}

\author{
Andrés Walliser, Instituto Juan March, Spain, andres@ceacs.march.es
}

This paper examines the case of Madrid with examples of mobilisation and transformative actions in public spaces of the city. It discusses how virtualisation of networks and spaces through ICTS (information and communication technologies) has contributed to new patterns of mobilisation and social networks among participants and supporters. Following sections will give an account of the transformation of political action in the real and virtual public space of Madrid and on the evolution of Spanish urban social movements in relation to these issues, and the role of new urban activists in the governance patterns of the neoliberal city in crises.

Key words: urban activism $\cdot$ social movements $\cdot$ Madrid $•$ neoliberal city

\section{Introduction}

This paper examines the case of Madrid in Spain with specific examples of mobilisation and transformative actions in public spaces of the city. First we will discuss how virtualisation of networks and spaces through ICTs (information and communication technologies) has contributed to new patterns of mobilisation and social networks among participants and supporters. The following sections will give an account on the transformation of political action in the real and virtual public space of Madrid and on the evolution of Spanish urban social movements in relation to these issues, and the role of new urban activists in the governance patterns of the neoliberal city in crises.

In the spring of 2011, following massive social mobilisations in different countries of the southern Mediterranean and Middle East, Spain experienced a wide range of protests. Thousands of citizens of all ages, but mainly youth, occupied the main square of Madrid, the Puerta del Sol, and created an encampment that lasted for weeks on end. Thousands more followed suit in other cities in the country. These were the so-called indignados (indignant, outraged) and they called for accountability, real democracy and above all, expressed general discontent with the political and economic system. Their claims revolved around, among other things, basic issues of accountability and the mechanisms of financial and political regulation control in relation to the causes and responsibilities of the current economic crises.

Prior to this movement, and after it, different urban actions and mobilisations have been taking place, mostly in the city of Madrid. Most involve the occupation of public space ranging from short ephemeral concentrations that temporarily appropriate a public space (people gathering in a given square to have breakfast 
together convoked through social networks), to more permanent interventions such as community gardens or self managed open social centres in publicly owned plots or buildings, or to community development plans for one of Europe's largest slums, the Cañada Real, with more than eight thousand residents. We have called these actions and mobilisations the New Urban Activists (NUA) and we consider them as part of a new kind of urban social movement in the Spanish context. These activists can be broadly defined as highly educated groups that use professional expertise for collaborative urban interventions in a context of social innovation ${ }^{1}$. Their outcomes have a transformative impact in many parts of the city, both in the city centre - more attractive for interventions for its historical lack of public space, its place symbolism and the identities that it contains - and in some of the most segregated urban environments at the outskirts of the city.

Most of these actions are new in the repertoire of action of the last two decades, and are an expression of the identity and skills of the NUA and also cover the gap that the crises, and especially the neoliberal restructuring that has come with it, have left in public services and community development at the neighbourhood level.

Both NUA and 15 May Mobilisations (hereafter referred to as $15 \mathrm{M}$ ) had new features in relation to other more 'traditional' forms of collective action ${ }^{2}$ by urban social movements in the Mediterranean cites, which relate to Castells' (1986) description of the right to the city as centering on issues of collective consumption (Castells, 1977) and residential claims seen in other cities in the region (Leontidou, 2010). The origin, participants, and dynamics of these more contemporary mobilisations, however, are new, the outcome of recent changes in how politically active citizens interact, network, cooperate, think and produce. One of the most innovative outcomes of the $15 \mathrm{M}$ was not only a demand for new forms of participation around specific issues, but also the emergence of a whole process that was multiple, spontaneous and deliberative following the call of an ad hoc platform called Democracia Real Ya (Real Democracy, Now!) $)^{3}$ (Alonso and Ardoz, 2011) ${ }^{4}$. As Pateman $(2012,7)$ argues:

In Western countries popular confidence in old-established institutions is fading, voters are disaffected, trust in government is declining and a very wide gap has opened up between citizens and governments and political elites more generally. Ordinary citizens' voices are now being heard loudly in a number of countries.

The $15 \mathrm{M}$ movement in Madrid can be interpreted as an outcome of previous social movement dynamics in which new forms of activism and mobilisation are being focused on the production of urban space. This has given rise to new groups and collectives pursuing the improvement of the city's community life through transformative action. Several authors have looked at $15 \mathrm{M}$ as the culmination of a series of protests that has endured and evolved over the last two decades (Sampedro, 2005; Haro and Sampedro, 20115 ; or Sadaba and Alcalde, 2009). For them, 15M and its predecessors have been defined as New Social Movements, especially the Movement for Housing Dignity (MHD), whose organisation featured the extensive use of information and communication technologies such as online fora and mailing lists. Both MHD and 15M were defined as paradigmatic cases of 'watching multitudes' (Haro and Sampedro, 2011). In contrast, the 13M movement, created after $11 \mathrm{March}$ 2004 train bombing in Madrid, was something closer to a 'SMS flash mob' (Alonso 
and Ardoz, 2011) or rather a 'smart mob' (Rheingold, 2002) with a politically explicit message. In this context Sampedro (2004) and Alcalde and Sadaba (2009) suggest updating the concept of 'political opportunity structure' (Tarrow, 1996) in relation to the possibilities offered by the mass and electronic media. Further, they define the 'media opportunity structure', which includes SMS and Internet (new media) to explain the $13 \mathrm{M}$ mobilisations in terms of new opportunities for action, due to the fast, decentralised and anonymous ways of disseminating information to spur mobilisation. Other authors such as Leontidou claim that the use of this conceptual framework 'marginalises spontaneous urban social movements in favour of more organised forms, which by definition compose a "strong civil society" $(2010,1181)$.

One may argue that in 2011 the conceptualisation of media opportunity structures changed further, with the advent of new forms for information exchange through smart phones and social networks. This has generated a change in the framework for collective action. This change relates to the way meanings are constructed for participants and their relation with the belief system. This is permanently evolving through the intense reception and exchange of information, knowledge transference and the generation and construction of networks around injustice frameworks (Snow and Benford, 2000). Injustice ${ }^{6}$ frames tend to appear in those movements advocating political and economic change. This applies to the movements mentioned so far: 15M, 13M.

In this paper we want to illuminate to what extent NUA are overlapping, complementing or even substituting traditional social movements. We seek to assess whether they have the capacity to become political actors and stakeholders in the city building process, and their role in new forms of urban governance. How do these new forms of activism contribute to or influence urban change and urban policy? To what extent can they shape public space and its use through mobilisation, networks and transformative action? Are there new forms of micro-level, highly localised urban interventions enhanced by the NUA's open source communities and identities?

\section{Commodification, gentrification and the transformation of political action in the real and virtual public space}

The various mobilisations in northern Africa and the Middle East, during the Arab Spring and the Spanish 15M movement, took place in radically different political and social contexts, but had certain commonalities: the sudden mobilisation of thousands through ICTs and the relevance of highly symbolic public spaces as (globally visible) stages for those mobilisations. The use of cyber or virtual space contributed to transform the meaning of public space in a context in which the flows of communication of the mainstream media are hierarchical and unidirectional, in contrast to the new multidirectional and horizontal flow of network communication. Online and offline practices as logistic tools have enhanced not only mobilisation, but also the exchange about global events information, knowledge and understanding in real time, access to blogs with opinions, articles, reactions of other political and social actors. Probably most relevant is how these tools have enhanced public and face-toface debates on both the web and in the streets. Some authors have referred to the complexity of these practices and contrasted them with traditional binary approaches opposing the 'virtual' realm and the 'real' realm as two different realities (Crang et al, 2007). This duality was forecast by the early theorists of the digital society, among 
them Guattari (1992) or Castells (2005). 'Real' - physical - space has been given the feature of something slow, solid, and somehow permanent in time, as compared with the flow and accelerated conditions of 'virtual' space. This reinterpretation of early approaches to the impact of ICTs on life and urban change has been confirmed with the successful (and exponential) eruption of social media sites such as Twitter, Facebook, Flickr or Linkedin. These new tools have new patterns of accessibility and are outcomes of both technological improvements and marketing strategies, which enhance the sensation that 'anything' can happen. The now real possibility of developing virtual identities, virtual networks and virtual knowledge in the city, enhances the consolidation of ideals, values and group identities.

In parallel, highly symbolic spaces, like some squares and streets in the city centre of Madrid, have gone through a process of commodification, changing from public places to become narrowly defined consumption spaces with an over-supply of consumption opportunities and easy access. As Rowe (1997) states, economic revitalisation can lead simultaneously to social devitalisation. These processes go in parallel with residential gentrification, which often brings a change in small retail businesses and economic activity in general. Gentrification has been thoroughly discussed elsewhere in relation to city centres and the strategies high income groups follow to settle and segregate themselves from low income and often ethnically different populations (Hamnett, 2003; Atkinson, 2006; Karsten, 2003, among others). But gentrification cannot be identified only with its most common version that implies the displacement of lower income residents and a certain homogenisation with the arrival of upper income residents with similar professional backgrounds (Beauregard, 1986; Smith, 1996). This is certainly part of the story, but not all. Gentrification can also be interpreted from a demand-side perspective, in which cultural values and identities come into play. Part of these include new ways of experiencing the city through social and political practice, redefining the use and perception of specific urban areas. For Ley (1996), this is the outcome of a new post-Fordist class and their progressive cultural values. Other authors argue strongly that gentrification affects mainly low income, vulnerable groups (Díaz Parra, 2009; Wacquant, 2008).

For Díaz Parra (2009) the colonisation of city centres is the result of a claim for social status epitomised in the symbolic value of that part of the city. We consider gentrification from a demand side following David Ley (1996), that is, from a social and cultural point of view rather than the materialist approach of authors such as Neil Smith (1996), who interpret the process from the supply side, that is, as a result of the cooperation of public administration and business to invest, renew and generate rent gaps that will accelerate the displacement of vulnerable residents. We certainly do agree with these arguments in explaining the logics of gentrification, but for the purpose of this paper we want to address the causes that make NUA mobilize and operate in such urban environments, and the incentives for their participants from a cultural and symbolic point of view. As Ley $(1996,53)$ argues, the new cultural class also has a geographical identity, which is far from incidental; like other social groups the relationship between place and identity is mutually reinforcing.

Demand-side analyses of gentrification have traditionally defined urban conflict in terms of traditional class structure (Marcuse, 2012), and set up a categorisation of different social groups around the LeFebvrian notion of the right to the city. This is now controversial. Changes in urban social structures and the current crises of the neoliberal urban growth regime challenge these initial assumptions because of 
fundamental changes in the contemporary political economy in cities. The borders between the destitute and the bourgeoisie are blurring although their positions and strategies remain different as Mayer $(2012,78)$ writes:

Instead, the political activism around producing the city today is carried out by disparate groups that share a precarious existence (whether in the informal sector, in the creative industries, or among college students), by middle class urbanites who seek to defend their quality of life, by radical autonomous, anarchist and alternative groups and various leftist organisations. These social groupings, though all are affected by contemporary forms of dispossession and alienation, occupy very different strategic positions within the post-industrial neoliberal city.

When we refer to the neoliberal city or 'neoliberalising cities' (Rosol, 2010) we are describing the dynamics through which the neoliberal ideology is applied to urban policy. Among other aspects, there is an increasing role of non-state actors that goes in parallel with the rising importance of civic engagement (Rosol, 2010) and its function to compensate the state's former welfarist functions (Mayer, 2003).

When we talk about urban social movements in southern Europe we have to bear in mind the particular context (Kazepov, 2005). The Mediterranean or familistic welfare model (Esping-Andersen, 1999) provides less public protection to the most vulnerable groups, but offers a support network based on the family. During the current, ongoing economic crisis, these structures have been overstressed and can no longer provide sufficient support for many families. Adolescents and young adults are becoming more and more vulnerable, despite middle class backgrounds and/or high levels of educational attainment. As we will see further on, these groups have become the main component of NUA.They possess growing awareness of downward mobility in light of fewer opportunities that would allow for upward mobility and the higher standards of living available to previous generations.

Different social groups redefine and negotiate their urban experiences and identities in those neighbourhoods that have a symbolic and aesthetic value for them, as well as positive material conditions such as accessibility and closeness to business and services. Gentrification can be expressed in terms of the use of space for leisure and consumption as well as for residential use, among others. Alternative youth of different social backgrounds hang out in some neighbourhoods of the city centre to discover the uniqueness of the 'authentic' urban experience of old quarters with their own urban logics, aesthetics, atmosphere and character. Later on through a process of gradual appropriation - gentrification in its different phases - they might become residents, as tenants, and further on as owners. The city centres have become not only highly symbolic for their traditional functions as sites of both history and consumption but also as containers of very specific lifestyles associated with modernity, independence, liberty. Also among the gentrifiers there are political attitudes and an ethos that might have the potential for political action as a way to achieve a more just and equal city. These are among that heterogeneous mixture that Mayer described above (Mayer, 2003).

In Madrid, large parts of the city centre have historically had a rather heterogeneous residential structure, with middle and low income groups working and living in the same streets or even buildings. Despite social and spatial integration, there is social 
exclusion and poverty among the most vulnerable groups, mainly ageing locals and residents of immigrant background. These vulnerable households coexist with shared flats by students, employed or unemployed professionals and younger families, which can face vulnerability due to the current economic crises. In other words, some groups identified as gentrifiers can become as vulnerable as the vulnerable population that they have substituted during the last three decades.

In Spain, through weeks of mobilisation and protest, the Spanish political class of all colours reacted first with astonishment and then with a certain form of rejection that ranged from moderation and self-criticism to open animosity depending on the political party. During the process hundreds of assemblies and meetings were held at the Puerta del Sol and other main squares in different cities. Participants publicly deliberated different issues, and articulated claims and demands in a participative way, after which they thoroughly prepared and disseminated meeting minutes. The $15 \mathrm{M}$ movement has since gradually transformed the assemblies into local action groups that correspond to the neighbourhoods of the city, focusing particularly on issues related to the right to the city, such as evictions and the right to housing.

The fact that $15 \mathrm{M}$ took place in Puerta del Sol, both the material centre of Madrid and the symbolic centre of the country's loose national identity, was crucial in the visualisation of the protest. Following the initial protest in Sol, hundreds of thousands of citizens replicated that event in similar emblematic spaces in other cities, towns and villages with different degrees of success. Sol, as it is known colloquially, became a public place in its classical meaning, after several 'renewal' projects that sought to prevent people staying at the square, and just passing by: no benches or seats and steel thorns on any horizontal surface. This transformation followed the current trends in most European cities in which some central public spaces become spaces to pass by, to avoid staying or meeting.

Following Lefebvre (1991), these spaces in Madrid and elsewhere have become public places due to social processes and practices. Lefebvre referred to the way in which urban space is built and defined. Often urban space, including public space, is the result of the sociocultural conditions and of political and economic rationales that leave a narrow margin for spontaneity in those processes and practices. We want to elaborate on the link between physical action and the way in which online and offline interactions can transform the temporalities and spatiality of urban life (Crang et al, 2007).

The case of Madrid is a good example. The old city centre is articulated around Puerta de Sol, which was renewed in the mid 19th century and made into the symbolic centre of the country. All the roads of the national network have their 'kilometre zero' reference point in Puerta del Sol. Since then it has been the site for various mass political events - the proclamation of the 2nd Republic in 1932, May 1st parades, and antiterrorist demonstrations among others. The first urban renewal plans under Franco's authoritarian rule sought to transform the square into a huge fascist public stage for parades and political gatherings. In the last two decades, the city's historical centre, which was traditionally a heterogeneous mix of residential, commercial, and public uses, has undergone a gradual trend towards thematisation (Muñoz, 2006).As in other historic city centres, food and fashion chains, as well as souvenir shops, have replaced individual retailers, in addition to many purveyors of basic supplies (groceries and so on). Some old markets have been rehabilitated as gourmet experience centres with leisure-oriented environments: the traditional market, now prohibitively expensive for 
most budgets, has become a leisure experience of decadent consumption. Traditional events like the celebration of New Year's Eve or more recently the Gay Pride parade have shifted the Puerta del Sol's character from a place in which to experience and consume special events into a daily spectacle of consumption. From the perspective of an ecology of public space, Puerta del Sol and its surroundings are becoming hybrid spaces $^{7}$ of consumption. There is an increasing dedifferentiation (Bryman, 2001) in the way consumption becomes part of experiencing the space in the old city, which turns into 'place' through the experience of buying, eating or appropriating typical - and stereotyped - products and urban landscapes.

Madrid's Distrito Centro ${ }^{8}$ has a dramatic lack of public spaces in a rather densely populated area. Most public spaces such as Sol, Callao, Plaza de España or Santo Domingo, are squares, which are part of the public space network mainly used by tourists or visitors, not so much by residents. A secondary network of public spaces is constituted by half a dozen small squares, which have undergone a process of semi-privatization by bar terraces and commercial events taking place in them. The recent renewal of some the biggest public spaces in the city centre (Callao, Santo Domingo, Plaza de la Luna) have pursued these aims through a 'hard square' design. The use of granite everywhere, flat surfaces with virtually no furniture or vegetation make them easy to survey, clean and rent for marketing or privately sponsored cultural events.

\section{New and old urban social movements in Madrid}

New actors have emerged in Madrid with claims that have implications for local political agendas and governance. Governance has started to incorporate civil society actors, traditionally excluded from the decision-making process at a participative level, and have now achieved some influence in urban policy, mainly with issues related to neighbourhood public space uses and security and the management of resources to fight social exclusion. Urban social movements, mainly represented by neighbours associations (Asociaciones de Vecinos), have traditionally articulated their capacity for conflict resolution through mobilisation and confrontation (Walliser, 2003).

Recent negotiations between neighbourhood associations and the local government have allowed the former a certain role in the design and implementation of neighbourhood development programmes (Blanco et al,2011). These Planes de Barrio allow neighbours' associations to manage the budget and human resources for a period of between one to three years on specific projects in areas such as education, social integration programmes and training.

In Spain, neighbours' associations have traditionally been very politicised and were linked with left-wing parties, mainly the Spanish Communist Party since the late 1960s, when they were illegal under Franco's authoritarian rule. During the 1970s and 1980s they had an active role in pushing forward traditional demands under the new democracy. Despite a first wave of cooptation of grassroots leaders by the majoritarian left-wing municipalities, conflict persisted around claims for better neighbourhoods (services, facilities, infrastructures, transport) and against speculation, especially in city centres. In the 1990 s and 2000s there was a decline in the activity and vitality of neighbourhood associations. Although some new issues were incorporated into their agendas, such as gender and immigration, a large number became de facto local service providers, for instance offering legal counselling, sport and leisure activities, with rather scarce resources. The leaders were ageing and few younger residents were 
coming forward to take their place. Despite this decline, in the last few years a number of associations have been revived and new young and well trained leaders have taken on management positions, as is the case of many associations in Madrid or Barcelona and specifically their umbrella organisations: FRAVM and FAVB' .

The new leaders are more pragmatic, and local governments, influenced by the so-called 'soft Europeanisation' have since early 2000 become more concerned with issues of participation (Atkinson and Rossignolo, 2010; Atkinson and Walliser, forthcoming). Often this concept of participation has not been fully interiorised by local administrations since European territorial cooperation does not constitute a coercive model of policy change through a supranational authority (Colomb, 2007, 350). The development of participative tools and their efficient implementation has to do with both the political culture of the city and the colour of its local government. For example in Madrid conflict has been sorted out through confrontation and mobilisation, using informal means of participation - political contacts between elected officials and the leaders. On the other hand, Barcelona has historically had a culture of consensus of negotiation, not to say that that confrontation and mobilisation does not occur (Walliser, 2003).

EU funded urban policy programmes like INTERREG ${ }^{10}$ enhanced applied research, as well as cooperation and exchange of knowhow between transnational partners that included different public and private (mainly non profit) stakeholders. The aim of these programmes is to develop new and innovative rules and policy tools shaped by the learning processes stimulated by the Directorate General on Regional Development on urban sustainable development. These programmes have stimulated new patterns of local governance with the inclusion of civil society stakeholders, but not necessarily efficient participatory schemes.

Although agencies, councils and participative mechanisms have been widely introduced in Madrid in the 2000s, most of them do little to enhance real participation if we understand it as the capacity of organised or individual citizens to influence the decision making, implementation and evaluation of public policies, specifically in programmes, actions and strategies (Walliser, 2003). Conversely it is still bottomup initiative and informal means of participation that manage to mobilise resources and open windows of opportunity for network governance. A good example are the Neighbourhood Plans ${ }^{11}$, which allowed the neighbours' associations and the FRAVM to design and manage local government investment in deprived areas. These plans provide a certain response to the impact of the crises since 2007 and reinforce some existing mechanisms for welfare and social service at sub-local level.

The access to resources and political power, in light of weak political opposition to the municipal government, has led to some institutionalisation of the neighbourhood association movement, which is largely represented in Madrid by the aforementioned hegemonic umbrella organisation FRAVM. Although this organisation has become the main counterpart for participation in the city, the confrontational strategy of mobilisations or political negotiation has still been effective, despite citizens' larger window of opportunity for participation. This is partly a result of the EU influence mentioned above and also of the local urban policy style, which is more incremental than strategic (Blanco et al, 2011). One of the issues around which neighbourhood associations have been actively mobilising is housing, especially supporting groups and actions that try to stop evictions through both active physical mobilisation at the moment of eviction and legal support and advice. 
Urban policy as such is not a concept used in Spanish policy or administrative jargon. There is a gradual, yet slow trend towards integrated approaches in urban regeneration processes, which include social, economic, physical and sustainable perspectives in area based projects. In Madrid, the term has been applied to deprived neighbourhood regeneration operations called ARI (Area de Rehabilitación Integral), but these operations mainly focus on subsidised housing renewal with very little to no emphasis on the other variables. Generally, the municipal government develops individual regeneration plans for different neighbourhoods, without a strategic approach to the city as a whole. There is little communication and interaction between different departments, which makes network governance more complicated. The municipal government has tried to address the lack of strategic integrated planning guidelines, but so far it has not implemented them, partly due to the crisis and high debt of the city of Madrid, as well as a lack of political will. The city government's stakeholders are the different departments involved in urban policy: planning, environment, public works, the Municipal Housing Corporation and economic development among others, and at the District level, social service department, police, culture and the Councillor's office.

Neighbourhood associations, mainly those under the FRAVM in the case of Madrid, have evolved, gained political influence and renewed their leadership with younger leaders. They have not achieved the introduction of routine participatory tools at the policy level, that is, in the regeneration process of deprived neighbourhoods or the transformation of public space. This has taken place very few times but mainly only after bottom-up demands on specific projects or in the experimental context of EU funded programmes.

\section{New Urban Activists and network governance}

In this section we will discuss the features of NUA in the case of Madrid, their character as social movements, and their role in the transformation of public space. We will also discuss whether they have helped to generate a new structure of network governance with the local government. NUA represent a new paradigm in relation to urban social movements since they are not formed around organised structures, but rather as a constellation of groups with a virtual logic that allows them to operate at the neighbourhood scale, and with an increasing visibility in the conventional media and the social media. Within NUA a learning process and new windows of opportunities are taking place fuelled by the sharing of information - collective intelligence - and a collaborative culture facilitated by the pro-commons philosophy.

In striving to portray the city as modern and innovative, local government has incorporated issues into the local political agenda that would have been considered transgressive in earlier epochs. From an aesthetic and practical point of view some of the actions described below are functional to the neoliberal city's image and to the current context of welfare retrenchment. In striving to create this image, city authorities sometimes engage with NUA, because of their low cost - both politically and economically - and their profile as avant-garde cultural producers. The professional profile of most participants in NUA (architects, sociologists, geographers, designers, lawyers and so on), many of them students, unemployed and/or self-employed, adds to their capacity for organisation and implementation. The activists are not linked to political parties. Furthermore many are critical of political parties and the economic system, as they view them as more or less the same thing. They share a set of ideals 
and values that go beyond party politics. NUA have a consolidated goal of reinforcing local democracy and aiming for a more just city.

The current economic crisis and Madrid's soaring debt (6600 million, 25\% of the debt of all Spanish municipalities) has led to massive budget cuts and the impossibility of assuming current or new investment in programmes and facilities. NUA actions often take place aside from public policy process and therefore hardly require any budget. Some actions have been fought against by the city government, especially those affecting private property, such as social centres in squatted premises, or even urban orchards in publicly owned vacant lots, but others have been tolerated in municipal property, mainly vacant plots in the city centre. The city's government, however, has not attempted to integrate NUA in urban policy strategies. Paradoxically and due to the atomisation of policies, some windows of opportunity have opened up in recent years from which NUA have benefited. For example, the cultural policy of the city, which has developed some flagship facilities of innovative art in the broadest sense, have sheltered and sponsored projects and actions of NUA under the label of art and creativity.

The two main flagship cultural facilities, Matadero Madrid and Medialab Prado, are open hubs for creation, exchange and often criticism for urban policies or social exclusion, among others, in the neoliberal city. The autonomy that the Department of Culture (Área de las Artes) has enjoyed in recent years, within a conservative local government, has aided these facilities in garnering international attention as creative, knowledge based and architectural urban successes. Such success stories form part of a wider strategy of city branding as defined by Colomb (2007) or Kratke (2004) on Berlin, in which the city government seeks to depict an image of modernity and tolerance much in line with Florida's (2002) quintessential creative city. One of the main tools to fulfil these aims is highly visible and innovative cultural policy. These spaces have been very useful to NUA through grants or the availability of space by operating as productive sites for networking, meeting and exchange in seminars, workshops and other social and cultural events. A good example of this is the VIC project (Citizen Initiative Incubator).

Madrid's neoliberal city government has different attitudes towards these movements that range from hostility through tolerance to acceptance. Issues related to private and public property appropriation, such as squatting, are rejected and often prosecuted with different degrees of severity. Squatted social centres are evicted as soon as the law allows it, even while squatter activists thoroughly plan and execute their next occupation. This is the case of Patio Maravillas ${ }^{12}$, which has become a kind of alternative symbol whose activities and goals move from one evicted squat to the next one. Some squatted social centres ${ }^{13}$ have profited from taking advantage of recently renewed buildings that are in a legal limbo after the owner's bankruptcy, often brought about by the crisis or illegal procedures in the permits. A good example is the squatted social centre (Centro Social Ocupado - CSO) Casablanca, a former old school transformed into luxury high standard apartments and lofts in the old city centre, which was about to be sold but the company broke up when the development went bankrupt. The squatter movement's lawyers discovered, among other irregularities, that the land was not authorised for residential use and private housing. The authorised land use was for facilities - it was an old school. In other cases a small urban orchard made by local neighbourhood groups ${ }^{14}$ has been dismantled to make way (or so the city claims) for 
the construction of a new medical centre which will take years to happen with most public investment eliminated by structural adjustment measures.

Tolerance comes after long and complex bureaucratic processes in which NUA are granted temporary leases of publicly owned vacant lots, like the community garden. For example, Esto es una Plaza (This is a square) ${ }^{15}$ holds workshops and cultural activities within a narrowly restricted opening schedule and constant constraints. The neighbours of the nearby blocks provide water and an electricity supply. Most of the activities involve street art and environmental education, such as guerrilla gardening, urban gardening, bike repair or building with recycled materials. This community garden is of great importance to the residents because of the lack of public space, especially green space, in the area.

Acceptance does not only come from local government. Private business schools imbued with the neoliberal city vision are including some cases and inviting certain groups to give lectures on their actions. The city also has allowed some groups in the context of tailored governance processes to develop innovative and autonomous cultural projects like Campo de la Cebada ${ }^{16}$, a large lot in the very centre of the city where a sports facility was demolished to build a proposed Olympic facility that stalled with the crisis. NUA gained use of the plot with the condition of a partnership with the local neighbourhood association that comanages its use.The FRAVM is regarded as the guarantor of the process. In a short time Campo de la Cebada has become a reference of a self managed public space and it is visited by international and local groups of students and professionals.

Probably the most striking case, for its dimensions, of a current NUA urban intervention, is the self-managed social centre (Centro Social Autogestionado - CSA) La Tabacalera ${ }^{17}$, an 18th century former tobacco factory owned by the state that has been leased to a network of groups La Red de Lavapies (associations of different kinds, covering different issues) in the neighbourhood of Lavapies, in the oldest part of Madrid. An initial one-year lease has been prolonged for another two. The centre, which occupies $8000 \mathrm{~m}^{2}$ of the old factory, is self managed. The centre holds all sorts of cultural activities like workshops, seminars and experiences for the local residents, an even mix of older low income working class residents, immigrants from more than a hundred countries and young and middle aged locals often engaged in NUA. There are also activities of all kinds that focus mostly on art and culture, sustainability and politics for a broader public. Recently tensions have arisen between some of the groups that manage the centre or develop the activities in it.

Despite the fact that most of the aforementioned experiences take place in the central district of the city, there are also some projects that operate in the less 'hip' outskirts, in vulnerable and deteriorating post war neighbourhoods such as $V$ for Virgen de Begoña $(\mathrm{VdB})$ a bottom-up community development project launched by Paisaje Transversal that has involved the local neighbourhood associations too. This group of architects has been working for more than a year with a local neighbours' association on developing a participative community development plan. The city was reluctant and not very collaborative at the beginning of the process but ended up tolerating and accepting it, although not taking it into account. An exhibition in City Hall and the refusal to include it in the Plan de Barrio, jointly with the reluctance of the FRAVM to share the resources allocated to it by the city, are a good example of how functional NUA can be and how the windows of opportunity narrow down when it relates to having a substantial role in the governance of urban regeneration. 
Todo por la Praxis ${ }^{18}$, another NUA group, has worked for many years in the biggest and most densely populated slum in western Europe, la Cañada Real, helping residents to design and build their own public spaces and facilities to learn and study, using recycled truck containers. They run a social and training centre for the youth and a General Plan for this linear 6km and more than 8000 residents, mostly immigrants, some locals and drug dealers - of what is one of the biggest drug-dealing points in Spain. Todo por la Praxis and other collectives have contributed to focus public attention on the dramatic living conditions of some of these groups, in a formerly forgotten and remote area of the city.

Most of these projects develop their own knowhow and share and improve those of others (see Table 1). There is an informal consensus to use open source, pro commons licences for sharing and disseminating information, and often groups collaborate on each other's projects. Two of these groups, Paisaje Transversal ${ }^{19}$ and Vivero de Iniciativas Ciudadanas (VIC), ${ }^{20}$ which are integrated into a Spanish based international network, Arquitecturas Colectivas, ${ }^{21}$ are elaborating a census of NUA in Madrid.The preliminary goal of this project is to create a consolidated database of important action groups, projects, and key actors.

\section{Understanding New Urban Activism}

In the following section we will discuss how the NUA have lead the transformation of devalued urban spaces transforming them into vibrant public spaces, cultural centres or potential scenarios of regeneration and social integration. We want to define the individuals and groups involved in them as new urban activists for they have specific features that explain the diverse transformative outcome and output of their actions.

These actions and projects have contributed to feed into movements such as $15 \mathrm{M}$, which above all is a reaction to the imposition of neoliberal policies at all administrative levels, from both neoliberal governments and social democrat ones applying neoliberal recipes. Furthermore, as mentioned earlier, the success of 15M's reorganisation and decentralisation after the spring 2011 national elections was also due to the previous experience of activists in different local groups and organisations and their existing networks.

In the 1970s, Castells defined urban social movements as a category of social movements that have been used in the literature until then. Social movements had an emphasis on organisational aspects of the movements. Later on new social movements were identified for incorporating new issues and repertoires of action. Castells had a broad emphasis on the context, the actors and therefore on results, while the new social movements theorists focus on organisation, context and repertoires of action and less on the way these had an impact of protest on the political system (Pickvance, 2003). Tarrow developed the political process theory (1996) with its main components for the movement formation: insurgent consciousness, organisational strength and political opportunities.

Our approach to NUA is twofold: while focusing on actors, we also consider the way they organise and interact, both among themselves and with the public administration. We argue that NUA are not exactly urban social movements or new social movements, although they share features of them, but rather they are a different expression of social action which seek to transform the city, share knowledge and contribute to a more just city, 
in a context in with the boundaries between activism, volunteer work and professional activity are blurry. NUA can be defined as a type of new urban social movements.

NUA have the following features:

- NUA has a loose organisational structure. It is articulated through groups that can range from one or two people to a dozen or more, and which are mostly defined by digital identities, rather than traditional formalised structures like the legal registration as association, group or movement. Formalisation is sometimes a prerequisite to consolidate their projects and become stakeholders in a governance network, but horizontal assembly logics prevail. Therefore we are talking about a constellation of groups and individuals with similar goals, strategies and repertoires of action that can operate independently of one another on their own projects. Collaboration and sharing of networks and results take place in a context of free access to information and knowledge.

- The lines between political action, mobilisation and professionalisation are blurry despite specific shared values. These politically active, mostly young and skilled professionals have a commitment to the moral values of the creative open source principles and seek to transform society through intervention in urban space. In a context of severe economic crisis, young professionals find they need to redefine their strategies to create professional activity. The last twenty years have witnessed the emergence and consolidation of the free or underpaid internship with the idea that the intern would acquire experience that would then lead eventually to a job. Now even qualified and experienced young professionals face unemployment or an underpaid job. It is becoming common among some professions (architecture, communication, design, and so on) to start an activity with others of the same interests and values that might lead to non profit, transformative (and political) action or to support bottom-up initiatives from social movements or citizens in need.

These actions are in some ways filling the void left by the traditional combination of social movements and/or NGOs as public service/expertise providers in the context of new public management, opening public policy implementation to civil society stakeholders. In the scenario of welfare state retrenchment there are cuts in expenditure and a reduction of service provision, with an increasing weight of responsibility of the voluntary sector.

- $\quad$ NUA movements studied here do not have many formal links or identification with established political organisations beyond the individual opinions of the activists. Furthermore there is desire for autonomy from political parties and institutions, and transformative action takes place mainly outside the purview of official bodies. This is partly an evolving outcome of the current economic and political crisis, but also a generational distinction for younger professionals who react to traditional mechanisms of political participation (Forbrig, 2005).

- Social innovation is a specific feature of NUA. One of the most distinctive elements of social innovation in relation to NUA is the consolidation of open source communities. Theoretical and practical knowledge is generated as collective intelligence through 'mass collaboration' (Leadbeater, 2008, in Loader 
and Mercea, 2011) in which everybody can participate. Projects, ideas, problems and solutions are broadcast to the community in a broad sense (Lahkani, 2006) and mutual exchanges feed the realm of collective intelligence. In the case of NUA, collective intelligence can be understood as collaborative intelligence. The use of social media has been described as a efficient means of participation as a citizen-centred perspective providing opportunities to connect the private sphere of autonomous political identity to a multitude of chosen political spaces (Loader and Mercea, 2011).

- The use of ICTs is a crucial tool to build identity, debate and mobilise on line, but also to 'de-virtualise' the digital community by encouraging real, offline interaction. Touraine (1977) forecasts the importance of information and knowledge management in the definition of conflict between two antagonistic sectors that struggle for the control of cultural interests. Technology was to determine the kind of transformative action that a society would perform. New technologies have certainly shaped the articulation of networks and collective action, but the question whether NUA are a product of ICTs or ICTs are just an instrument to achieve certain ends needs to be discussed. Some authors claim that ICTs have been key in determining the shape of new kinds of social movements (Roehlinger and Brown, 2009; Reid and Chen, 2007). They often refer to big movements that use ICTs to mobilise around global issues such as Jihadist or anti-war movements and so on. Often the use of ICTs is based on evidence of internet use, as Earl et al (2010) examine in their fruitful attempt to explain activism through this means of communication. These resources are still being used with different strategies such as Bennett and Segerberg (2012) explain for the 2009 G20 meeting in London when they compare two movements: 'Put people first' and 'G20 Meltdown'. The first one put an emphasis on the personalisation of both participation and collective goals, while the second one used it mainly to call for action.

The scope of NUA is much more modest, but ICTs still play a critical role in enhancing structures (or rather quasi structures), interaction, networking and visualisation of contents and actions. NUA use ICTs not only to communicate and share information, but also to stimulate offline activity within the sphere of the city. This activity espouses a certain political ethos around ideas of the just city. The speed at which ICTs evolve, and the promptness with which they are incorporated as tools for mobilisation, diffusion or visualisation makes theorising a difficult exercise. Smart phones, Twitter, Skype, the blogosphere or open source software like Livestream Procaster, are changing and reinventing on a day-today basis the role of ICTs in the way activists organise, produce knowledge and share it. Digital identities elaborated on Facebook, Twitter or personal/group blogs offer a means of horizontal activist interaction, substituting the websites and chats that were at the forefront of internet activism only five years ago.

As ICTs increasingly encourage individual visibility and expression on the web, it will also encourage more fragmented activisms (and social movements?). These activisms, meanwhile, will be more likely to interact and operate in horizontal networks, sharing, transforming and building together common systems of beliefs. NUA actively promote certain philosophies embedded with moral values about equal opportunity and access to information through the use of tools such as 
Creative Commons and other open source technologies, which make possible the production of (counter) culture, knowledge and information, on the one hand, and also of new professional and activist scenarios.

- $\quad$ NUA have a heterogeneous social and political composition based more on generational and ideological traits than strictly on social class. Activists, often highly educated, are facing the end of the certainties of the past decades epitomised in the access to labour market after training, the access to welfare state benefits or the consolidation of a process of individual emancipation through the achievement of the economic, cultural and social autonomy. Their cultural capital and education does not exclude them as mentioned above from destitution and actual or potential social exclusion in different forms.

- NUA have a capacity to promote, network and function both by reacting to public administration, through bottom-up autonomous actions, and collaborating with it, by taking advantage of programmes and grants available from public (local) funding. The latter are not significant, but provide visibility and reinforce the network. Most of their actions run on a low budget and intensive personal and individual work. Projects often are developed with no economic reward, except some donations of materials and small amounts of money.

- $\quad$ NUA, through the use of ICTs and its locally based projects, have the agency to place political debate in parallel to that of the mainstream social media, and to compete with it (Loader and Mercea, 2011; Castells, 2012) by gaining visibility, challenging mainstream opinions in the media and broadcasting their ideas and visions both in and out of their communities.

\section{Conclusion: towards new initiatives for urban empowerment in a context of welfare state retrenchment?}

In this article I have tried in an exploratory way to describe and analyse the features and potential of NUA having influence in the arenas of urban public space and social innovation in Madrid, and assess their potential impact in the network governance pattern of the city. Prior to that I have defined the main features of these groups, which have evolved in parallel to urban and new social movements out of the specific conditions of the urban political economy in Spain: the neoliberal city engaged in growth machines, new technologies and the availability of activists who are developing new forms of political activism through urban intervention in relation to current socio- economic conditions in times of severe crisis.

My first two questions were to what extent NUA are overlapping, complementing or even substituting traditional social movements as a new urban social movement? Do they have the capacity to become political actors and stakeholders in the city building process, and their role in new forms of urban governance?

NUA have appeared on the scene in a relatively short time and in the context of a favourable political opportunity structure. The crisis of the 90s was followed by a period of growth and a real estate bubble that affected greatly urban policy and development, but also brought with it some openings for participation in some aspects of urban policy, namely neighbourhood regeneration from an integrated approach. Network governance schemes were developed in which the traditional urban social movements in Madrid, mainly the FRAVM, engaged in dialogue and collaboration 
with the local government in an increasingly neoliberalised city. In this context NUA developed with completely new tools and strategies such as ICTs, open source communities and collaborative intelligence. These achieved high visibility and results that the local urban social movements have not achieved before. The development of new kinds of projects around public space and urban transformation has somehow overshadowed the role of the traditional urban social movements. NUA in Madrid have an immense potential for transformative actions, for the consolidation of existing projects and actions, and for their contribution to a renaissance of community life at the neighbourhood and city level, with capacity for visibility and effectiveness.

The current situation of crises in a neoliberal city has benefited NUA in two ways. First, by enhancing NUA to realise some of their projects through punctual agreements with local government, and second, by profiting from a tolerant cultural policy that seeks to brand the city as innovative and progressive.

The value of these two features is on the one hand very relevant in terms of the consolidation of the networks, the reinforcement of their capacity of action and the production of knowledge and its exchange. On the other hand, their role as stakeholders in the governance pattern of the city still remains unclear in two ways. In the first place there are questions over how long the current status quo will last in relation to the 'interim use' of most of the projects analysed here. This depends largely on the collapse of urban policy initiatives of the City of Madrid due to its appalling budgetary situation.

Second, most NUA are facing a situation in which they are in an impasse between creativity and political action, and their professional futures. Despite this some do better that others. In general the success of their projects is due largely to the dedication and energy invested in them in a context of unemployment or underemployment of their work as activists. How sustainable this situation is for the protagonists remains uncertain.

The current municipal strategy is to tolerate and/or accept NUA and their actions, but once the economic situation changes and private and especially public investors come back to the city, the current arrangements would very likely lose their validity. The attitude of the local government can be seen as a stopgap measure or a second best option (Rosol, 2010).

NUA are stakeholders within the network governance of the city but with far less capacity of negotiation than FRAVM, and their capacity to stay and consolidate depends on the external factors mentioned jointly with the political will of the local government to open windows of opportunity for them in the normative realm (as formal participative tools), and the ability of NUA to gain a role as key political actors.

Still, the road seems to be cleared for the moment for NUA.Their role as stakeholders is evolving through a gradual process with specific windows of opportunity and bottom-up pressure, rather than from the political will of local authorities. NUA are becoming stakeholders within the network governance of the city. To some extent they have taken on tasks that traditional neighbourhood associations did not cover, due to NUA's greater technical qualifications and network capacity. The challenges NUA are facing on the other hand are their non-organisational strategy and inexperience in negotiation as stakeholders, the difficult sustainability in the long run, the introduction of much more critical political issues that challenge current neoliberal urban policy, and the competition with firmly settled urban social movements that are showing some ambiguity between reluctance and collaboration. 
The second set of questions was the following: How do these new forms of activism contribute to or influence urban change and urban policy? To what extent can they shape public space and its use through mobilisation, networks and transformative action? Are there new forms of micro-level, highly localised urban interventions enhanced by the NUA's open source communities and identities? Regarding the effects of NUA's urban intervention, it has to be said that those projects that aim at public space are having a very positive effect in a short time and with an undetermined future time span. Some of their achievements are visibility in the city, a meeting point for the neighbourhood and beyond, to raise political awareness and interact as open source communities or just users of the cultural and social activities. Those other projects that involve more complex scenarios such as Cañada Real or Barrio de Begoña $(\mathrm{VdB})$ are more dependent on political will and the capacity of other social stakeholders (residents, neighbours' associations and ultimately the FRAVM) to share their privileged position in the governance scheme and to accept to openly collaborate with them. NUA need to be regarded as real, solid actors by the other stakeholders.

In relation to my last question, NUA are certainly developing new ways of transforming the city at a micro level. New ways of working, project design and implementation bring fast and high quality outcomes. The innovative aspects of NUA in relation to other urban social movements (low organisational forms, open source communities, collaborative intelligence and independence from political institutions) makes this micro local special dimension turn these projects into reference points at an international level.

NUA are covering successfully many shortcomings of the traditional urban social movements. Their role in urban governance is still to be consolidated and is uncertain in the long run due to contextual variables and the nature of the NUA themselves. What is certain is that so far their urban interventions have transformed and produced urban public space in an unforeseen way.

\section{Notes}

${ }^{1}$ Following Phillips et al's (2008) definition, social innovation is a novel solution to a social problem that is more effective, efficient, sustainable, or just than existing solutions and for which the value created accrues primarily to society as a whole rather than private individuals.

${ }^{2}$ Pickvance $(2003,106)$ argues that urban social movements have been 'usually categorized as an old social movement like the labour movement, because of the allegedly material character of their demands'.

${ }^{3}$ Democracia Real ¡Ya! is a social movement that defines itself as non-partisan, nonunionised, pacific, against being part of any ideology, but not apolitical. It was one of the organizers of the demonstrations of May 15th 2011, and supported the people that decided to camp and occupy some public spaces in main Spanish cities. These events were the origin of $15 \mathrm{M}$ movements. Democracia Real ¡Ya! considers that citizens are not represented, nor are heard by political representatives, and thus demands a change in current economic and financial policies. This group has focused since its origins on three especially vulnerable groups: the unemployed, the evicted and the vulnerable youth. In April 2012 the movement split into two: those who wanted to become an association and have an organisational structure and those who choose to stay as a movement with an assembly structure. (http://www.democraciarealya.es) 
${ }^{4}$ The $15 \mathrm{M}$ movement was analysed in the days of its initial mobilisation in spring 2011 by Calvo, Gómez Pastrana and Mena (2011) through an on-site survey. It came out that the participants were mainly between nineteen and thirty years old, although throughout the mobilisation the average age increased, as did public opinion support (up to 88\%) (Castells, 2012, 122). Seventy per cent had a university degree or were studying for it. Participants regarded themselves as reformist, rather than seeking rupture looking for general changes in the way politics is organised. Their specific goals did not appear to be neatly defined. Most of the participants identify themselves with the left (78\%) on a scale of 1 to 10 . Most of them vote (56\%) but mainly for small parties or with blank ballots. There were two main kinds of participants: those who just participated in the demonstrations and concentrations that lasted weeks, and those who also slept in the camps in public places, participated in the organisation and logistics, and took part in the debates that took place. Finally, most of the participants were digital natives (Presky, 2004, cited by Calvo, Gómez Pastrana and Mena) and have used the ICTs, mainly social networks such as Facebook or Twitter, to learn about the calls for demonstrations, exchange information or inform themselves to what was going on in real time (65\%), although personal networks were also important (34\%) (Presky, 2004, cited by Calvo, Gómez Pastrana and Mena).

${ }^{5}$ These cycles are the result of rather regular flows of civil disobedience every five years (Sampedro, 2005; Haro and Sampedro, 2011). The mobilising factors vary across time but have a background in leftist protests. They have ranged from resisting military service when it was still compulsory, demanding an increase of the percentage of GDP allocated to development and aid funds; protesting against the management of an oil spill in the sea of Galicia, denouncing the politicisation of the March 11th 2004 terrorist attacks in Madrid (March 13th movement, or 13M), opposing the war in Iraq and finally to promoting the Movement for Housing Dignity (MHD), which began in 2003.

${ }^{6}$ For a discussion on the notions of the just and the unjust city, see Fainstein's introduction to The just city (2010).

${ }^{7}$ Hybrid spaces are those in which publicness is increasingly enacted simultaneously through a complex of concrete and virtual qualities, of static and mobile domains, of public and private spheres, of global and local interests. Wireless and mobile technologies are making not only the physical and the virtual but also the private and the public run into each other more and more (Seijdel 2006, 4).

${ }^{8}$ Madrid is divided into 21 districts and has 3.3 million inhabitants. Distrito Centro comprises the city centre with its very centre in Puerta del Sol and had 149,000 residents, of whom $22.8 \%$ were immigrants as of 2012 .

http://www.madrid.es/portal/site/munimadrid/menuitem.ec7bec4d2ccca0aa7d245f01 9fc08a0c/?vgnextoid=dfd9ef637004a010VgnVCM100000d90ca8c0RCRD)

Districts in Madrid have little political autonomy and are responsible only for some administrative issues. Municipal government is divided into departments. This political style had some exceptions in the 1980s, 1990s and early 2000s in places such as Barcelona, where a more consensus based style guided the relations between neighbourhoods associations and the city. Confrontation as a political style of conflict resolution can be understood as a paradox of Spain's social movements. Workers' movements have had traditionally a strong anti-partisan culture. 'New social movements' which appeared very late (1980s-1990s) in comparison with other European countries did so in a context of a civil society very influenced by left-wing political parties (Alvarez Junco, 1994; Della Porta and Diani, 2012). 
${ }^{9}$ FRAVM stands for Federación Regional de Asociaciones de Vecinos de Madrid, this is the Regional Federation of Neighbourhood associations of Madrid. FAVB is the same for the city of Barcelona. They have 230 and 100 associations affiliated to each one. In the case of Madrid FRAVM is the most influential leftist organisation in the urban governance infrastructure even beyond the social democrat and the united left parties that sit in the city council in minority.

${ }^{10}$ http://www.interreg4c.eu/about_programme.html

${ }_{11}$ Neighbourhood Plans are a policy at the neighbourhood level that seeks to redress some imbalances in vulnerable areas through employment strategies, social programs etc. They are paid by the city but managed by the neighbour's associations. Thirty of them have been developed in the last four years.

${ }^{12} \mathrm{http}: / /$ defiendelo.patiomaravillas.net/

13 http://www.csocasablanca.org/

14 http://ccaa.elpais.com/ccaa/2012/05/16/madrid/1337201703_211601.html

15 http://estaesunaplaza.blogspot.com.es/

16 http://elcampodecebada.org/

17 http://latabacalera.net/

18 http://www.todoporlapraxis.es/

19 http://www.paisajetransversal.org/

20 http://viveroiniciativasciudadanas.net/

21 http://arquitecturascolectivas.net/

\section{References}

Alcalde, J, Sadaba, I, 2009, Nouvi media e azione collettiva nella Spagna contemporánea: Gli evento del marzo 2004, Partecepazione e Conflitto, 1, 69-95

Alonso, A, Ardoz, I, 2011, El 15M y la quinta columna, Teknokultura, 8, 2, 187-205

Alvarez-Junco, J, 1994, Los nuevos movimientos sociales del modelo tradicional a la modernidad postfranquista, in Gusfield, J, Laraña, E, Los nuevos movimientos sociales. De la ideología a la identidad, Madrid: CIS

Atkinson, R, 2006, Padding the bunker: Strategies of middle-class disaffiliation and colonisation in the city, Urban Studies, 43, 4, 819-32

Atkinson, R, Rossignolo, C, 2010, Cities and the 'soft side' of Europeanization: The role of urban networks, in Hamedinger,A, Wolffhardt,A (eds), The Europeanization of cities: Impacts on urban governance and on the European system of governance, Amsterdam: Techne Press

Atkinson, R, Walliser, A, forthcoming, Do we really want to learn? EU funded urban programmes and their impact on policy and strategy, in Andersen, HT, Atkinson, $\mathrm{R}$ (eds), Production and use of urban knowledge, London: Springer

Beauregard, R, 1986, The chaos and complexity of gentrification, in Smith, N, Williams, P, Gentrification of the city, London: Unwin Hyman

Benford, RD, Snow, DA, 1988, Ideology, frame resonance, and participant mobilisation, in Klandermans, B, Kriesi, H, Tarrow, S (eds), International social movement research, Vol 1, From structure on action: Comparing social movement research across cultures, 197-217, Greenwich, CT: JAI Press

Benford, RD, Snow, DA, 2000, Framing processes and social movements: An overview and assessment, Annual Review of Sociology, 26, 611-39 
Bennett, W, Segerberg, A, 2012, The logic of connective action, Information, Communication \& Society, 15,5, 739-768

Blanco, I, Walliser, A, Bonet, J, 2011, Urban governance and regeneration policies in historic city centres: Madrid and Barcelona, Urban Research and Practice, 4, 3, 326-43

Bryman, A, 1999, The Disneyization of society, The Sociological Review, 47, 1, 2547

Calvo, K, Gómez-Pastrana, T, Mena, L, 2011, Zoom político: Especial 15-M fundación alternativas, http://www.falternativasorg/laboratorio/actividades/presentaciones/ disponible-el-numero-4-2011-de-la-coleccion-zoom-politico-especial15-m-17711

Castells, M, 1977, The urban question: A Marxist approach, London: Edward Arnold

Castells, M, 1986, La ciudad y las masas, Madrid:Alianza

Castells, M, 2005, La sociedad red i la era de la información: Economía, sociedad y cultura, Madrid: Siglo XXI

Castells, M, 2012, Redes de indignación y esperanza, Madrid: Alianza

Colomb, C, 2007, The added value of transnational cooperation: Towards a new framework for evaluating learning and policy change, Planning Practice and Research, 22, 3, Special Issue:The Europeanization of spatial planning through territorial cooperation, 347-72

Crang, M, Crosbie, T, Graham, S, 2007, Technology, time-space, and the remediation of neighbourhood life, Environment and Planning A, 39, 2405-22

Della Porta, D, Diani, M, 2012, Los movimientos sociales, Madrid: CIS

Democracia Real:Ya!, 2012, http://wwwdemocraciarealyaes/

Díaz Parra, I, 2009, Procesos de gentrificación en Sevilla en la coyuntura reciente análisis comparado de tres sectores históricos: San Luis-Alameda, Triana y San, Barcelona: University of Barcelona

Earl, J, Kimport, K, Prieto, G, Rush, C, Reynoso, K, 2010, Changing the world at one webpage at a time: Conceptualizing and explaining internet activism, Mobilisation, $15,4,425-46$

Esping-Andersen, G, 1999, The social foundations of post-industrial economies, Oxford: Oxford University Press

Fainstein, S, 2010, The just city, Ithaca: Cornell University Press

Florida, R, 2002,The economic geography of talent, Annals of the Association of American Geographers, 92, 4, 743-55

Forbrig,J, 2005, Introduction: Democratic politics, legitimacy and youth participation, in Forbrig, J (ed), Revisiting youth political participation challenges for research and democratic practices in Europe, Strasbourg: Council of Europe

Guattari, F, 1992, The Guattari reader: Collected essays and interviews, London: Blackwell

Hamnett, C, 2003, Gentrification and the middle-class remaking of Inner London, 1961-2001, Urban Studies, 40, 12, 2401-26

Haro Barba, C, Sampedro, V, 2011, Activismo político en la red: Del movimiento por la vivienda digna al 15M, Teknokultura Revista de Cultura Digital y Movimientos Sociales, 8, 2, 167-85

Karsten, L, 2003, Family gentrifiers: Challenging the city as a place to simultaneously build a career and to raise children, Urban Studies, 40, 12, 2573-84

Kazepov,Y, 2005, Changing contexts, local arrangements, and the challenge to local cohesion, in Kazepov, Y (ed), Cities of Europe: Changing contexts, local arrangements, and the challenge to local cohesion, London: Routledge 
Krätke, S, 2004, City of talents? Berlin's regional economy, socio-spatial fabric and 'worst practice' urban governance, International Journal of Urban and Regional Research, 283, 511-29

Lahkani, K, 2006, Open source science: A new model for innovation, in Harvard Business School Working Knowledge, Boston: Harvard Business School, 1-3

Leadbeater, C, 2008, We-Think: Mass innovation not mass production, London: Profile Books

Lefebvre, H, 1974, Donaldson-Smith, N (trans), The production of space, Oxford: Blackwell, 1991

Leontidou, L, 2010, Urban social movements in 'weak' civil societies: The right to the city and cosmopolitan activism in southern Europe, Urban Studies, 47, 6, 1179-1203

Ley, D, 1996, The new middle class and the remaking of the central city, Oxford: Oxford University Press

Loader, D, Mercea, D, 2011, Networking democracy?, Information, Communication and Society, 14, 6, 757-69

Marcuse, P, 2012, Whose right(s) to what city? in Brenner, N., Marcuse, P., Mayer, M. (eds.) Cities for people, not for profit: Critical urban theory and the right to the city, London: Routledge

Mayer, M, 2003, The onward sweep of social capital: Causes and consequences for understanding cities, communities and urban movements, International Journal of Urban and Regional Research, 271, 110-32

Mayer, M, 2012, The 'right to the city' in urban social movements, in Brenner, N, Marcuse, P, Mayer, M (eds), Cities for people not for profit: Critical urban theory and the right to the city, London: Routledge

Muñoz, F, 2006, Paisajes banales: Bienvenidos a la sociedad del espectáculo, in SoláMorales, I, Costa, X (eds), Metropolis: Ciudades, redes, paisajes, Barcelona: Gustavo Gili

Pateman, C, 2012, Participatory Democracy Revisited, Perspectives on Politics, 10, 1, 7-19

Pickvance, C, 2003, From urban social movements to urban movements: A review and introduction to a symposium on urban movements, International Journal of Urban and Regional Research, 27, 1, 102-109

Reid, E, Chen, H, 2007, Mapping the contemporary terrorism research domain, International Journal of Human-Computer Studies, 65, 1, 42-56

Rheingold, H, 2002, Smart mobs: The next social revolution, Tennessee: Perseus Books

Roehlinger, D, Brown, J, 2009, Democracy, action and the internet after 9/11, American Behavioural Scientist, 53, 1, 133-50

Rosol, M, 2010, Public participation in post-Fordist urban green space governance: The case of community gardens in Berlin, International Journal of Urban and Regional Research,34, 3, 548-563

Rowe, PG, 1997, Civic realism, Cambridge MA: MIT

Sádaba Rodríguez, I,AlcaldeVillacampa,J, 2009, Nuovi media e azione collettiva nella Spagna contemporanea: Gli eventi del marzo 2004, Partecipazione e Conflitto, 1, 69-95 Sampedro,V (ed), 2005, 13 M multitudes on line, Madrid: Los Libros de la Catarata

Seijdel, J, 2006, Hybrid space: Public agency in the network society, Open, 11, 2-4

Smith, N, 1996, The new urban frontier: Gentrification and the revanchist city, London: Routledge

Tarrow, S, 1996, States and opportunities:The political structuring of social movements, in McAdam, D, McCarthy, JD, Zald, MN, Political opportunity structure, mobilizing structures and cultural framings, London: Cambridge University Press 
Touraine, A, 1977, The self-production of society, Chicago: The University of Chicago Press.

Walliser, A, 2003, Participación y ciudad, Madrid: Instituto Juan March

Walliser, A, Moreno, J, Bruquetas, M, 2005, La Regeneración de barrios desfavorecidos, Working Paper 67/2005, Madrid: Fundación Alternativas

Waquant, L, 2008, Relocating gentrification: The working class, science and the state in recent urban research, International Journal of Urban and Regional Research, 32, 1, 198-205 